Jurnal Akuntansi Manajerial

ISSN (E): 2502-6704

Vol. 6, No. 1 Januari - Juni 2021: 1-19
Dipublikasikan oleh Fakultas Ekonomi dan Bisnis

Universitas 17Agustus 1945 Jakarta

http://journal.uta45jakarta.ac.id/index.php/JAM

\title{
Studi Komparatif Terhadap Perencanaan Pajak Dan Manajemen Laba Perusahaan (Perusahaan Transportasi Darat Yang Terdaftar Di Bursa Efek Indonesia Pada
}

Tahun 2015-2019)

\author{
Robiur Rahmat Putra1, Yhoga Pranata ${ }^{2}$, Shiva Dewanti N², Aulia Al Qori H², \\ Ramlah $^{2}$ \\ ${ }^{1}$ Dosen Program Studi Akuntansi ${ }^{2}$,Mahasiswa Program Studi Akuntansi \\ Fakultas Ekonomi \& Bisnis Universitas 17 Agustus 1945 Jakarta \\ e-mail: robiur.rahmat@uta45jakarta.ac.id
}

\begin{abstract}
ABSTRAK
Tujuan dari penelitian ini adalah untuk menjelaskan bagaimana signifikansi perbedaan perencanaan pajak dan manajemen laba perusahaan transportasi darat yang terdaftar di BEI tahun 2015 - 2019. Perencanaan pajak diukur dengan Tax Retention Rate (TRR) dan manajemen laba diukur dengan Pendekatan distribusi laba. Sampel penelitian ini sebanyak 6 perusahaan transportasi darat yang diperoleh melalui metode purposive sampling. Penelitian ini menggunakan teknik analisis data Analysis of Variance (ANOVA). Hasil penelitian menunjukkan bahwa perencanaan pajak dan manajemen laba perusahaan transportasi darat yang terdaftar di BEI pada tahun 2015-2019 tidak memiiki perbedaan yang signifikan. Dapat dilihat pula bahwa perbandingan rata-rata perencanaan pajak dan manajemen laba untuk masing-masing perusahaan tidaklah jauh berbeda.
\end{abstract}

\section{ABSTRACT}

The purpose of this study is to explain the significance of differences in tax planning and earnings management of land transportation companies listed on the IDX in 2015 - 2019. Tax planning is measured by the Tax Retention Rate (TRR) and earnings management is measured by the profit distribution approach. The samples of this study were 6 land transportation companies which were obtained through purposive sampling method. This study uses the Analysis of Variance (ANOVA) data analysis technique. The results show that the tax planning and earnings management of land transportation companies listed on the IDX in 2015-2019 do not have a significant difference. It can also be seen that the comparison of the average tax planning and earnings management for each company is not much different
Info Artikel

Diterima: 05 Maret, 2021

Revisi: 06 Mei 2021

Dipublikasi Online: 30 Juni 2021

\section{Kata kunci :}

Perencanaan Pajak, Manajemen Laba, Perusahaan Transportasi Darat.

Article History

Received: March 05, 2021

Revised: May 06, 2021

Published Online: Juny 30,2021

Keywords:

tax planning, earnings management, land transportation companies. 
Jurnal Akuntansi Manajerial

ISSN (E): 2502-6704

Vol. 6, No. 1 Januari - Juni 2021: 1-19
Dipublikasikan oleh Fakultas Ekonomi dan Bisnis

Universitas 17Agustus 1945 Jakarta

http://journal.uta45jakarta.ac.id/index.php/JAM

\section{PENDAHULUAN}

Laporan keuangan disusun sebagai wujud tanggung jawab manajemen dalam mengelola sumber daya yang dimiliki oleh perusahaan. Penyusunan laporan keuangan bertujuan untuk menyajikan informasi mengenai kinerja keuangan perusahaan. Pemerintah dalam hal ini menggunakan informasi dalam laporan keuangan untuk menetapkan kebijakan pajak (Ikatan Akuntan Indonesia, 2007). Penyusunan laporan keuangan dengan menggunakan pendekatan akrual memberikan kesempatan bagi manajemen untuk berperilaku oportunis. Dengan menggunakan pendekatan akrual, setiap transaksi atau peristiwa. diakui pada saat terjadinya dan dicatat serta dilaporkan dalam laporan keuangan periode yang bersangkutan (Ikatan Akuntan Indonesia, 2007). Namun, penggunanaan pendekatan akrual ini dimanfaatkan oleh pihak manajemen untuk melakukan perubahan penilaian, metode akuntansi, serta penggeseran biaya dan pendapatan untuk meningkatkan kesejahteraan dan kepentingan pribadi (Achyani \& Lestari, 2019).

Dalam 10 tahun terakhir, yakni pada 2008-2018, penerimaan perpajakan mengalami pertumbuhan moderat atau alamiah sebesar 9\%. Namun, dalam 5 tahun terakhir, penerimaan perpajakan tercatat melambat karena hanya tumbuh 7,2\%. Dalam dokumen Kerangka Ekonomi Makro dan Pokok-Pokok Kebijakan Fiskal (KEM PPKF) 2020, pemerintah menyebutkan beberapa alasan perlambatan penerimaan perpajakan yang terjadi dalam 5 tahun terakhir.

Penerimaan Perpajakan dan Pertumbuhan (Triliun Rupiah)

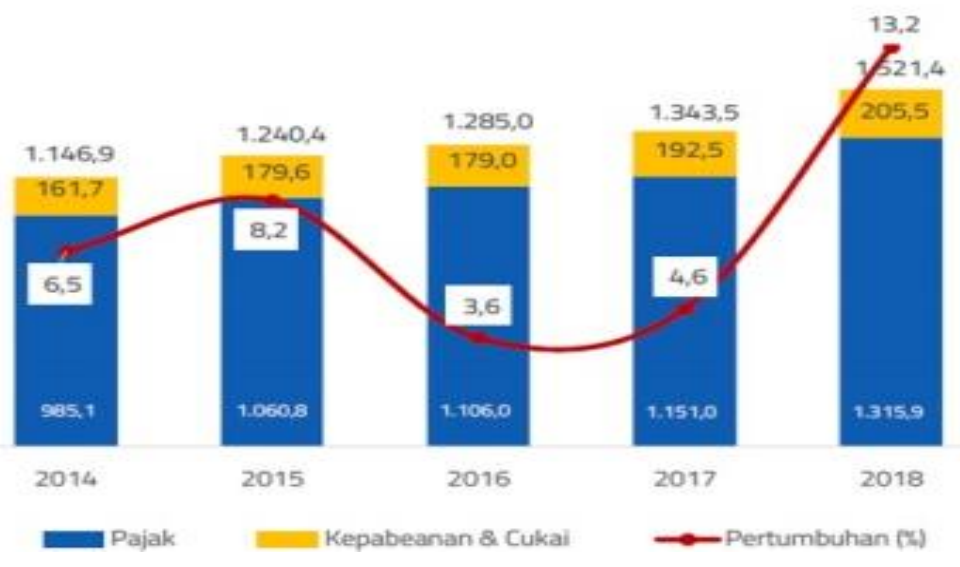

Sumber : KEM PPKF 2020

2 | J A M Vol. 6, No. 1 Januari - Juni 2021 
Jurnal Akuntansi Manajerial ISSN (E): 2502-6704

Vol. 6, No. 1 Januari - Juni 2021: 1-19
Dipublikasikan oleh Fakultas Ekonomi dan Bisnis Universitas 17Agustus 1945 Jakarta http://journal.uta45jakarta.ac.id/index.php/JAM

Adanya kontraksi basis pajak karena kebijakan seperti kenaikan penghasilan tidak kena pajak (PTKP), pengecualian dari pengenaan pajak, serta insentif pajak lainnya. Dalam jangka pendek, kebijakan ini akan mengurangi penerimaan perpajakan. Selanjutnya kegiatan underground economy dan sektor informal yang belum tercatat dengan baik di sistem perpajakan serta pelemahan harga komoditas dunia, terutama pada komoditas minyak dan gas, serta batubara. Adapun beberapa kebijakan atau program yang berpengaruh pada kinerja penerimaan perpajakan terjadi pada tahun-tahun tertentu. Salah satunya program tersebut adalah pengampunan pajak (tax amnesty). Program ini berpengaruh pada kinerja 2016 - 2017.

Pendapatan negara hingga akhir Agustus 2019 mencapai Rp 1.189,3 triliun atau 54,9 persen dari target APBN 2019 sebesar Rp 2.165,1 triliun. Angka ini naik sebesar 3,2 persen dibandingkan periode yang sama tahun lalu yang hanya Rp 1.152,9 triliun. (kemenkeu.go.id). Sampai dengan akhir Agustus kondisi perekonimian di berbagai negara tidak cukup menggembirkan kecuali sedikit negara yang bisa. Realisasi APBN sampai akhir Agustus pendapatan kita hanya mencapai Rp 1.189,3 triliun, dalam Konferensi Pers APBN kementrian keuangan mengatakan penerimaan negara itu antara lain berasal dari penerimaan perpajakan yang tembus mencapai Rp 920,2 triliun. Angka ini mencapai 51,5 persen dari target APBN 2019. Angka ini pun tumbuh tipis 1,4 persen dibandingkan realisasi periode yang sama tahun lalu sebesar Rp 907,5 triliun.

Fenomena Perusahaan jasa penyewaan transportasi PT Adi Sarana Armada Tbk (ASSA) membukukan kenaikan laba tahun berjalan yang diatribusikan ke entitas induk $61,31 \%$ di semester I 2018.

\begin{tabular}{|c|c|c|}
\hline \multicolumn{3}{|c|}{ PT. ADI SARANA ARMADA Tbk (ASSA) } \\
\hline & 2017 & 2018 \\
\hline Laba & 46,89 Milliar & 75,64 Milliar \\
\hline Pendapatan & 812,41 Milliar & 884,75 Milliar \\
\hline Beban Perusahaan & 570.47 Milliar & 596,88 Milliar \\
\hline Margin Laba Kotor & $29,78 \%$ & $32,54 \%$ \\
\hline
\end{tabular}

Sumber Data: laporan keuangan PT Adi Sarana Armada Tbk 
Jurnal Akuntansi Manajerial ISSN (E): 2502-6704

Vol. 6, No. 1 Januari - Juni 2021: 1-19
Dipublikasikan oleh Fakultas Ekonomi dan Bisnis

Universitas 17Agustus 1945 Jakarta http://journal.uta45jakarta.ac.id/index.php/JAM

Mengutip laporan keuangan perusahaan, pada semester I 2017 lalu, laba ASSA tercatat Rp 46,89 miliar, naik menjadi Rp 75,64 miliar.Lonjakan laba ini terjadi di tengah kenaikan pendapatan yang hanya satu digit. Pendapatan Adi Sarana Armada naik 8,90\% dari Rp 812,41 miliar di semester I 2017 menjadi Rp 884,75 di semester I 2018. Sementara kenaikan beban perusahaan naik lebih tipis yakni 4\% dari Rp 570,47 menjadiRp 596,88 miliar.Beban pokok pendapatan ASSA memang naik. Tapi, kenaikan ini hanya 4,63\%, lebih rendah daripada kenaikan pendapatan Adi Sarana Armada. Alhasil, margin laba kotor emiten ini naik dari 29,78\% menjadi 32,54\% .

Fenomena lain dalam manajemen terjadi pada Kinerja laba PT Express Transindo Utama Tbk (TAXI) merosot cukup dalam pada 2015. Penurunan laba emiten jasa transportasi darat tersebut terjadi di tengah pendapatan usaha yang masih tumbuh.Faktor penyebab anjloknya laba TAXI adalah meningkatnya beban operasional, terutama beban bunga dan beban langsung yang signifikan pada 2015. Selain itu, persaingan ketat di antara perusahaan taksi juga ikut mengganjal laba perseroan.Berdasarkan laporan keuangan tahun 2015 yang dipublikasikan BEI, Rabu (13/4), laba TAXI anjlok 72,8\% menjadi Rp32,25 miliar (Rp15,03 per saham) pada 2015, dari Rp118,71 miliar (Rp55,33 per saham) pada tahun 2014. Penurunan laba ini disebabkan antara lain oleh peningkatan beban bunga TAXI sebesar 33,4\% jadi Rp205,369 miliar.Di sisi lain, beban langsung TAXI juga naik 28\% menjadi Rp629,034 miliar. Akibatnya, laba kotor perseroan turun 14,3\% menjadi Rp341,06 miliar. Adapun laba usaha emiten transportasi darat beraset Rp2,88 triliun pada 2015 - turun 4,3\% dari Rp3,01 triliun pada 2014 - itu merosot 15,4\%, dari Rp283,51 miliar menjadi Rp239,91 miliar pada 2015.Uniknya, di tengah kinerja laba TAXI yang merosot tajam pada 2015, pendapatan usaha perseroan justru masih tumbuh 9\%, dari Rp889,723 miliar menjadi Rp970,093 miliar.

Dari uraian di atas dimana dalam lima tahun terakhir ditemukan ada perusahaan transportasi yang mengalami penurunan laba dan ada juga yang mengalami peningkatan dapat disimpulkan bahwa perencanaan pajak dilakukan perusahaan untuk meminimalkan pembayaran pajak, Sementara efisiensi beban pajak penghasilan dilakukan sebagai upaya untuk menekan jumlah kewajiban pajak dengan secara legal yaitu penanganan dan pengelolaan pajak dengan melakukan perencanaan pajak secara efektif. Dari hasil penelitian terdahulu terdapat ketidak konsistensian (research gap) yang menjadikan penelitian ini menarik untuk diteliti kembali. Perbedaan penelitian ini dengan penelitian terdahulu adalah peneliti menambahkan study comparative yaitu 
Jurnal Akuntansi Manajerial ISSN (E): 2502-6704

Vol. 6, No. 1 Januari - Juni 2021: 1-19
Dipublikasikan oleh Fakultas Ekonomi dan Bisnis

Universitas 17Agustus 1945 Jakarta

http://journal.uta45jakarta.ac.id/index.php/JAM

peneliti akan membandingkan seberapa signifikan perbedaan perencanaan pajak dan manajemen laba perusahaan dalam 5 tahun terakhir yang kita akan menghitung seberapa besarkah perusahaan dalam melakukan manajeman laba dan perencanaan pajak, serta seberapa signifikan kah perbedaan antar perusahaan dalam melakukan perencanaan pajak dan manajemen laba.

\section{TUJUAN PENELITIAN}

a. Untuk mengetahui apakah terdapat perbedaan yang signifikan perencenaan pajak pada perusahaan transportasi subsektor transportasi darat.

b. Untuk mengetahui apakah terdapat perbedaan yang signifikan manajemen laba pada perusahaan transportasi subsektor transportasi darat.

\section{KAJIAN TEORI}

\section{Manajemen Laba}

Munculnya praktik manajemen laba yang dilakukan oleh manajemen dilandasi oleh dua teori, yaitu agency theory (teori keagenan) dan positive accounting theory (teori akuntansi positif).

\section{a. Agency Theory (Teori Keagenan)}

Hapsari \& Manzillah, (2016) mendefinisikan hubungan keagenan sebagai suatu kontrak di mana satu atau lebih principal (pemilik) menggunakan pihak lain atau agent (manajer) untuk menjalankan perusahaan. Dalam teori keagenan, yang dimaksud dengan principal adalah pemegang saham atau pemilik yang menyediakan fasilitas dan dana untuk kebutuhan operasi perusahaan. Agent adalah manajemen yang memiliki kewajiban yang mengelola perusahaan sebagaimana yang telah diamanahkan principal kepadanya.

Agency theory memiliki asumsi bahwa masing-masing individu semata- mata termotivasi oleh kesejahteraan dan kepentingan dirinya sendiri. Pihak principal termotivasi mengadakan kontrak untuk menyejahterakan dirinya melalui pembagian dividen atau kenaikan harga saham perusahaan. Agent termotivasi untuk meningkatkan kesejahteraannya melalui peningkatan kompensasi. Konflik kepentingan semakin meningkat ketika principal tidak memiliki informasi yang cukup tentang kinerja agent karena ketidak mampuan principal memonitor aktivitas agent dalam perusahaan. Sedangkan agent mempunyai lebih banyak informasi mengenai kapasitas diri, lingkungan kerja, dan perusahaan secara keseluruhan. Hal inilah yang mengakibatkan adanya ketidakseimbangan informasi yang dimiliki oleh princi-

pal dan agent dan dikenal dengan istilah asimetri informasi. Asimetri informasi dan konflik 
Jurnal Akuntansi Manajerial ISSN (E): 2502-6704

Vol. 6, No. 1 Januari - Juni 2021: 1-19
Dipublikasikan oleh Fakultas Ekonomi dan Bisnis

Universitas 17Agustus 1945 Jakarta

http://journal.uta45jakarta.ac.id/index.php/JAM

kepentingan yang terjadi antara principal dan agent mendorong agent untuk menyembunyikan beberapa informasi yang tidak diketahui oleh principal dan menyajikan informasi yang tidak sebenarnya kepada principal, terutama informasi tersebut berkaitan dengan pengukuran kinerja agent.

\section{b. Positive Accounting Theory (Teori Akuntansi Positif)}

Teori yang dipelopori oleh Watts dan Zimmerman, (2016) memaparkan bahwa faktor-faktor ekonomi tertentu bisa dikaitkan dengan perilaku manajer atau para pembuat laporan keuangan. Dan et al., (2018) menyatakan bahwa teori akuntansi positif merupakan bagian dari teori keagenan. Hal ini dikarenakan akuntansi teori positif mengakui adanya tiga hubungan keagenan, yaitu (1) antara manajemen dengan pemilik (the bonus plan hypothesis), (2) antara manajemen dengan kreditur (the debt to equity hypothesis), dan (3) antara manajemen dengan pemerintah (the political hypothesis).

\section{Perencanaan Pajak (Tax Planning)}

Perencanaan pajak (tax planning) merupakan bagian manajemen pajak dan merupakan langkah awal di dalam melakukan manajemen pajak. Puji Astutik, (2016) mendefinisikan perencanaan pajak (tax planning) sebagai proses mengorganisasi usaha wajib pajak atau sekelompok wajib pajak sedemikian rupa sehingga utang pajak, baik PPh maupun beban pajak yang lainnya berada pada posisi yang seminimal mungkin. Tujuan perencanan pajak adalah untuk merekayasa usaha wajib pajak agar beban pajak dapat ditekan serendah mungkin dengan memanfaatkan celah-celah peraturan perpajakan yang ada untuk memaksimalkan jumlah laba setelah pajak, karena dalam hal ini pajak merupakan unsur pengurang laba

Sumomba \& Hutomo, (2012) menjelaskan bahwa ada beberapa cara yang dapat dilakukan oleh Wajib Pajak untuk meminimalkan beban pajak, diantaranya yaitu:

a) Pergeseran pajak (tax shifting) adalah pemindahan atau mentransfer beban pajak dari subjek pajak kepada pihak lainnya. Dengan demikian, orang atau badan yang dikenakan pajak dimungkinkan sekali tidak menanggung beban pajaknya.

b) Kapitalisasi adalah pengurangan harga objek pajak sama dengan jumlah pajak yang akan dibayarkan kemudian oleh pihak pembeli. 
Jurnal Akuntansi Manajerial ISSN (E): 2502-6704

Vol. 6, No. 1 Januari - Juni 2021: 1-19
Dipublikasikan oleh Fakultas Ekonomi dan Bisnis

Universitas 17Agustus 1945 Jakarta

http://journal.uta45jakarta.ac.id/index.php/JAM

c) Transformasi adalah cara pengelakan pajak yang dilakukan oleh perusahaan dengan cara menanggung beban pajak yang dikenakan terhadapnya.

d) Penggelapan pajak (tax evasion) adalah penghindaran pajak yang dilakukan secara sengaja oleh wajib pajak dengan melanggar ketentuan perpajakan yang berlaku. Penggelapan pajak (tax evasion) dilakukan dengan cara memanipulasi secara ilegal beban pajak dengan tidak melaporkan sebagian dari penghasilan, sehingga dapat memperkecil jumlah pajak terutang yang sebenarnya.

e) Penghindaran Pajak (Tax Avoidance) adalah usaha wajib pajak untuk meminimalkan beban pajak dengan cara menggunakan alternatif-alternatif yang riil yang dapat diterima oleh fiskus. Maturidi, (2017) menyebutkan Penghindaran Pajak (Tax Avoidance) adalah rekayasa "tax affairs" yang masih tetap dalam bingkai peraturan perpajakan yang ada.

\section{Penelitian Terdahulu}

Konsep dasar penelitian ini mengacu pada fenomena yang terjadi pada perusahaan transportasi darat yang mana dalam lima tahun terkahir terdapat perusahaan yang memili kenaikan laba dan ada juga beberapa perusahaan yang melaporkan penurunan labanya bahkan melaporkan kerugianya. Dengan adanya hal tersebut penelitian ini lebih menekan kan pada komperatif antar perusahaan terkait perencanaan pajak dan manajemen labanya.

Penelitian terdahulu yang menjadi referensi bagi penulis adalah adalah (Husain et al., 2016) dengan judul Praktik Manajemen Laba Studi Komparasi Pada Perusahaan - Perusahaan yang Melakukan IPO Tahun 2012-2016 Hasil pengujian hipotesis menunjukkan bahwa tidak terdapat perbedaan yang signifikan antara perusahaan industri manufaktur dan sektor keuangan yang melakukan IPO tahun 2012-2016. Berbeda halnya dengan (Maturidi, 2017) meneliti tentang Studi Komparatif Praktik Earnings Management Pada Bank Konvensional dan Bank Syariah Di Indonesia Dan Malaysia. Hasil penelitian menunjukkan bahwa terdapat perbedaan praktik manajemen laba antara bank konvensional dan bank syariah. 


\section{Kerangka Konseptual}

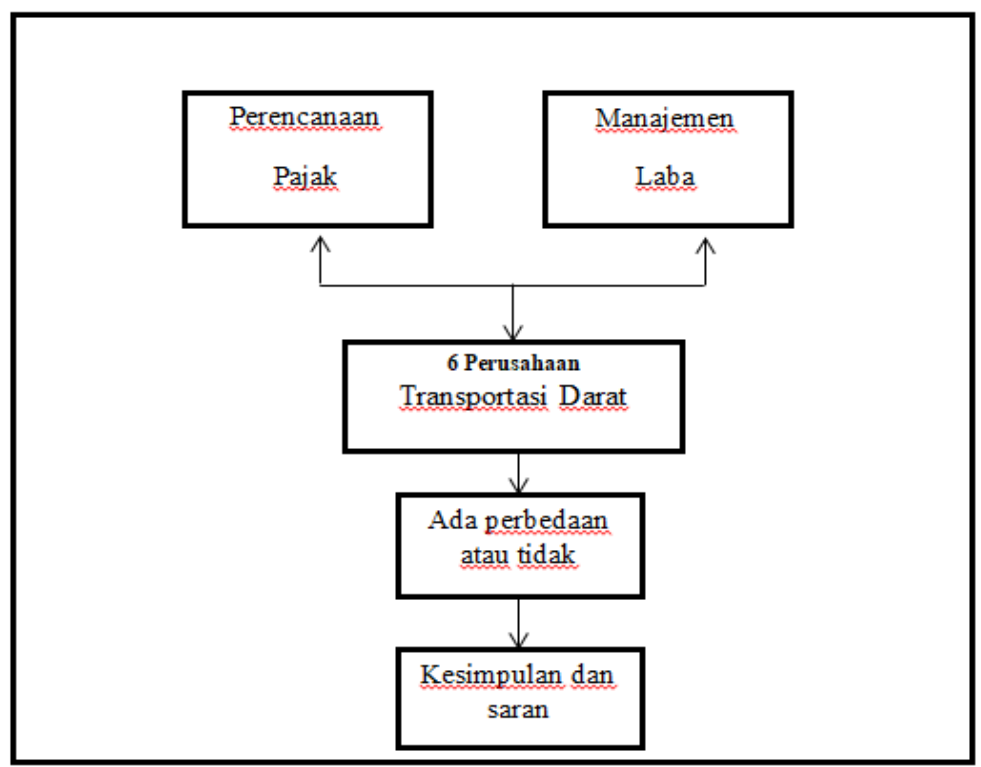

\section{Pengembangan Hipotesis}

Pajak penghasilan merupakan salah satu sektor pajak yang paling besar menyumbang penerimaan negara. Pada tahun 2009, tarif PPh Badan mulai menganut sistem tarif tunggal (single tax) yaitu sebesar 28\%, yang sebelumnya menggunakan sistem tarif berlapis. Mulai tahun 2010, tarif PPh Badan mengalami penurunan menjadi 25\% dan berlaku hingga saat ini. Jadi berapapun penghasilan kena pajaknya, tarif yang dikenakan adalah satu yaitu $25 \%$. Selain itu, bagi perusahaan yang masuk bursa (go public) diberikan penurunan tarif sebesar 5\% dari tarif normal dengan syarat lainnya. Dengan begitu, pada tahun pajak 2009 tarif perusahaan yang masuk bursa (go public) sebesar 23\% dan pada tahun pajak 2010 sebesar 20\%. Karena adanya perubahan (penurunan) tarif tunggal PPh badan dari tahun 2009 ke tahun 2010 yang berlaku hingga saat ini, hal ini dapat memberikan insentif dan peluang kepada perusahaan untuk melakukan manajemen laba, dengan cara memperkecil laba kena pajak (taxable income), yang akan menyebabkan beban pajak perusahaan akan semakin kecil. Dengan adanya keinginan pihak manajemen untuk menekan dan membuat beban pajak sekecil mungkin, maka pihak manajemen cenderung untuk meminimalkan pembayaran pajak dengan berbagai upaya, sepanjang kegiatan tersebut masih berada di dalam peraturan perpajakan yang berlaku. Upaya untuk meminimalkan beban pajak ini sering disebut dengan perencanaan pajak (tax planning). Perusahaan transportasi darat yang memiliki asset yang besar tentunya akan lebih diawasi oleh pemerintah khusus nya dalam pem- 
Jurnal Akuntansi Manajerial ISSN (E): 2502-6704

Vol. 6, No. 1 Januari - Juni 2021: 1-19
Dipublikasikan oleh Fakultas Ekonomi dan Bisnis

Universitas 17Agustus 1945 Jakarta

http://journal.uta45jakarta.ac.id/index.php/JAM

bayaran pajaknya. Hal ini menyebabkan perusahaan besar cendrung tidak berani melakukan perencanaan pajak. Berbeda dengan perusahaan yang memiliki asset yang kecil, perusahaan tersebut cendrung berani melakukan perencanaan pajak karena mereka merasa tidak terlalu diawasi oleh pemerintah.

Berdasarkan landasan teori dan hasil penelitian sebelumnya, penulis merumuskan hipotesis sebagai berikut:

\section{Ha1: Ada perbedan Perencanaan pajak antara ke-6 perusahaan transportasi darat.}

Berdasarkan Penelitian Terdahulu berhasil menunjukkan bahwa ada perbedaan manajemen laba yang dilakukan perusahaan. Sejalan dengan (Nuariyanti \& Erawati, 2014), (Suputra, 2017), dan (Ayu, 2019) penelitian mereka membuktikan bahwa beberapa variabel seperti perencanaan pajak, kewajiban pajak tangguhan, dan manajemen laba memiliki perbedaan. Penelitian yang dilakukan Maturidi, (2017) meneliti tentang Studi Komparatif Praktik Earnings Management Pada Bank Konvensional dan Bank Syariah Di Indonesia Dan Malaysia. Hasil penelitian juga menunjukkan bahwa terdapat perbedaan praktik manajemen laba antara bank konvensional dan bank syariah.

Berdasarkan landasan teori dan hasil penelitian sebelumnya, penulis merumuskan hipotesis sebagai berikut:

\section{Ha2: Ada perbedaan manajemen laba antara ke-6 perusahaan transportasi darat.}

\section{METODE PENELITIAN}

\section{Jenis Dan Sumber Data}

Jenis penelitian ini merupakan penelitian kuantitatif dengan data yang digunakan yaitu data sekunder yang bersumber dari laporan keuangan tahunan perusahaan yang terdaftar di Bursa Efek Indonesia tahun 2015 - 2019. Data diperoleh dengan cara mengakses website PT Bursa Efek Indonesia di www.idx.co.id. dan website resmi masing-masing perusahaan.

\section{Populasi, Sampel, Dan Tekhnik Pengambilan Sampel}

Populasi pada penelitian ini adalah perusahaan transportasi sub sektor transportasi darat yang terdaftar di Bursa Efek Indonesia pada periode pengamatan tahun (2015 - 2019). Pengambilan sampel dalam penelitian ini menggunakan teknik purposive sampling yaitu pengambilan 
Jurnal Akuntansi Manajerial

ISSN (E): 2502-6704

Vol. 6, No. 1 Januari - Juni 2021: 1-19
Dipublikasikan oleh Fakultas Ekonomi dan Bisnis

Universitas 17Agustus 1945 Jakarta http://journal.uta45jakarta.ac.id/index.php/JAM

sampel dengan menggunakan kriteria tertentu. Adapun kriteria pengambilan sampel adalah sebagai berikut:

1. Perusahaan transportasi sub sektor transportasi darat yang terdaftar di BEI dan mempublikasikan laporan keuangan auditan secara konsisten dan lengkap.

2. Periode laporan keuangan tersedia secara tahunan .

3. laporan keuangan tersedia dari tahun 2015 - 2019 di Bursa efek Indonesia dan website masing - masing perusahaan.

4. Perusahaan yang tidak di-delisting selama periode pengamatan.

5. Laporan keuangan menggunakan mata uang negara Indonesia (IDR).

6. Melaporkan data yang dibutuhkan peneliti.

\section{Perencanaan Pajak (X1)}

Pada penelitian ini untuk mencari perbandinganya/comparative dari perencanaan pajak diukur dengan menggunakan metode sebagai berikut :

Tax Retention Rate (TRR) atau tingkat retensi pajak dengan rumus sebagai berikut:

$$
\mathrm{TRR}=\frac{\text { Net Income } i t}{\operatorname{Pretax}(E B I T)}
$$

Keterangan :

- $\quad$ TRR $_{\text {it }}$

- Net Income It - Pretax Income $(\text { EBIT) })_{i t}=$ Laba sebelum pajak perusahaan i pada tahun $t$ $=$ Laba bersih perusahaan i pada tahun $\mathrm{t}$

$=$ Tax Retention Rate (tingkat retensi pajak) perusahaan $\mathrm{i}$ pada tahun $\mathrm{t}$ 
Jurnal Akuntansi Manajerial

ISSN (E): 2502-6704

Vol. 6, No. 1 Januari - Juni 2021: 1-19
Dipublikasikan oleh Fakultas Ekonomi dan Bisnis

Universitas 17Agustus 1945 Jakarta

http://journal.uta45jakarta.ac.id/index.php/JAM

\section{Manajemen Laba (X2)}

Pada penelitian ini untuk mencari perbandinganya/comparative dari manajemen laba diukur dengan menggunakan metode sebagai berikut:

Rumus pendekatan distibusi laba yaitu (Philips et al., 2003):

$$
\Delta E=\frac{E_{i t}-E_{i t-1}}{M V E_{t-1}}
$$

Keterangan:

- $\mathbf{E} \quad=$ perubahan laba

- $\mathbf{E}_{\mathrm{it}} \quad=$ laba perusahaan i pada tahun $\mathrm{t}$.

- $\mathbf{E}_{\mathrm{it}-\mathbf{1}}=$ laba perusahaan i pada tahun $\mathrm{t}-1$.

- MVE $_{\mathbf{t}-1}=$ Market Value of Equity perusahaan i pada tahun t-1.

\section{HASIL DAN PEMBAHASAN}

Perusahaan transportasi darat merupakan perusahaan yang bergerak dalam bidang jasa pelayanan transportasi darat. Perusahan transportasi di Indonesia dalam masa ke masa banyak mengalami penurunan pendapatan yang begitu signifikan, hal ini di tandai dengan banyak nya jasa transportasi darat yang muncul dan bersaing untuk menarik hati pelanggan untuk menggunakan jasa transportasi yang di kembangkan nya, dalam lima tahun terakhir peneliti mengamati banyak perusahaan transportasi darat yang mengalami kerugian bahkan sekelas perusahaan transportasi darat yang sudah menerbitkan saham di bursa efek Indonesia banyak juga yang mengalami kerugian dari waktu ke waktu. Berdasarkan fenomena yang ada peneliti tertarik akan meneliti tentang perencanaan pajak dan manajemen laba perusahaaan transportasi sub sektor transportasi darat yang telah terdaftar di bursa efek Indonesia. 
Jurnal Akuntansi Manajerial ISSN (E): 2502-6704

Vol. 6, No. 1 Januari - Juni 2021: 1-19
Dipublikasikan oleh Fakultas Ekonomi dan Bisnis

Universitas 17Agustus 1945 Jakarta http://journal.uta45jakarta.ac.id/index.php/JAM

Berdasarkan sumber yang di peroleh dari PT Bursa Efek Indonesia peneliti telah mengumpulkan seberapa banyak perusahaan transportasi di bursa efek Indonesia, berikut adalah jumlah perusahaan transportasi yang terdaftar di bursa efek Indonesia.

Tabel 1

\section{Daftar Jumlah Perusahaan Sampel}

\begin{tabular}{|l|c|}
\hline Jumlah perusahaan transportasi yang terdaftar di BEI & 46 \\
\hline Jumlah perusahaan yang bukan transportasi darat & 33 \\
\hline Jumlah perusahaan yang di delisting selama periode pengamatan & 3 \\
\hline Jumlah perusahaan yang tidak melaporkan secara lengkap & 4 \\
\hline Jumlah perusahaan transportasi darat yang masuk kriteria dan diteliti & 6 \\
\hline $\begin{array}{l}\text { Lama waktu pengamatan 5 tahun, dan jumlah sampel sebanyak 6 perusahaan } \\
\text { sehingga jumlah N dalam penelitian ini sebanyak }\end{array}$ & 30 \\
\hline
\end{tabular}

Berdasarkan data yang di peroleh serta berdasarkan kriteria penelitian ini terdapat enam perusahaan transportasi darat yang masuk kriteria penelitian ini, berikut adalah daftar nama perusahaan yang masuk kriteria penelitian

Table 2

Daftar Nama Sampel Perusahaan

\begin{tabular}{|c|c|l|}
\hline No & Kode Perusaahaan & Nama Perusahaan \\
\hline 1. & BIRD & PT BLUE BIRD Tbk \\
\hline 2. & ASSA & PT ADI SARANA ARMADA Tbk \\
\hline 3. & LRNA & PT EKA SARI LORENA TRANSPORT Tbk \\
\hline 4. & TAXI & PT EXPRES TRASINDO UTAMA Tbk \\
\hline 5. & MIRA & PT MITRA INTERNATIONAL RESOURCH Tbk \\
\hline 6. & WEHA & PT WEHA TRANSPORT INDONESIA Tbk \\
\hline
\end{tabular}

Keenam perusahaan tersebut telah memenuhi kriteria dari metode purposive sampling dalam penelitian ini, perusahan - perusahaan tersebut menarik di teliti karena dalam pelaporan keuangan khususnya di bagian perpajakan dan laba nya banyak kejanggalaan dan peneliti juga akan menguji apakah setiap peerusahaan memiliki perencanaan pajak dan manajemen laba yang berbeda, untuk mengatuhi seberapa besar persamaan atau perbedaan perusahaan melakukan perencanaan pajak dan manajemen laba maka akan du uji menggunakan serangkaian pengujian di bawah ini. 
Jurnal Akuntansi Manajerial

ISSN (E): 2502-6704

Vol. 6, No. 1 Januari - Juni 2021: 1-19
Dipublikasikan oleh Fakultas Ekonomi dan Bisnis

Universitas 17Agustus 1945 Jakarta

http://journal.uta45jakarta.ac.id/index.php/JAM

\section{ANALISIS DESKRITIF}

Table 3.

Analisis Deskriftif

\begin{tabular}{|c|c|c|c|c|c|c|c|}
\hline \multicolumn{8}{|c|}{ Descriptives } \\
\hline & & $\mathrm{N}$ & Mean & Std. Deviation & Std. Error & Minimum & Maximum \\
\hline \multirow{7}{*}{$\begin{array}{l}\text { Perencanaan } \\
\text { Pajak }\end{array}$} & $\mathrm{BIRD}$ & 5 & 753,60000 & 10,358571 & 4,632494 & 737,000 & 762,000 \\
\hline & ASSA & 5 & 722,00000 & 75,242940 & 33,649666 & 601,000 & 781,000 \\
\hline & LRNA & 5 & 982,60000 & 125,675375 & 56,203737 & 761,000 & 1058,000 \\
\hline & TAXI & 5 & 934,00000 & 262,062970 & 117,198123 & 637,000 & 1350,000 \\
\hline & MIRA & 5 & 388,80000 & 1085,664405 & 485,523882 & $-1342,000$ & 1297,000 \\
\hline & WEHA & 5 & 739,60000 & 70,440045 & 31,501746 & 657,000 & 841,000 \\
\hline & Total & 30 & 753,43333 & 462,070653 & 84,362173 & $-1342,000$ & 1350,000 \\
\hline \multirow{7}{*}{$\begin{array}{l}\text { Manajemen } \\
\text { Laba }\end{array}$} & BIRD & 5 & 93,00000 & 6106,965081 & 2731,117811 & $-12563,000$ & 3639,000 \\
\hline & ASSA & 5 & 31,60000 & 58,058591 & 25,964591 & $-41,000$ & 92,000 \\
\hline & LRNA & 5 & 13,60000 & 463,634878 & 207,343821 & $-628,000$ & 615,000 \\
\hline & TAXI & 5 & 29,80000 & 2206,361190 & 986,714721 & $-3213,000$ & 2904,000 \\
\hline & MIRA & 5 & 42,00000 & 111,982141 & 50,079936 & $-123,000$ & 155,000 \\
\hline & WEHA & 5 & 10,20000 & 73,288471 & 32,775601 & $-60,000$ & 126,000 \\
\hline & Total & 30 & 36,70000 & 2620,672271 & 478,467106 & $-12563,000$ & 3639,000 \\
\hline
\end{tabular}

Sumber data: Data diolah dengan SPSS versi 25.0

Berdasarkan table diatas terlihat bahwa rata rata tertinggi perencanaan pajak di lakukan oleh Perusahaan Eka Sari Lorena Tbk (LRNA) dengan jumlah rata-rata sebesar 982,60000 sedangkan jumlah minimumnya sebesar 761,000 dan jumlah maksimumnya sebesar 1058,000. selanjutnya Perusahaan Expres Trasindo Utama Tbk (TAXI) memiliki jumlah rata-rata sebesar 934,00000 dengan nilai minimum 637,000 dan nilai maksimum sebesar 1350,000. Perusahaan Blue Bird Tbk (BIRD) memiliki rata-rata perencanaan pajak sebesar 753,60000 dengan nilai minimum 737.000 dan nilai maksimum sebesar 762.000. pada Perusahaan Adi Sarana Armada Tbk (ASSA) memiliki jumlah rata-rata perencanaan pajak mencapai 722,00000 dengan nilai minimumnya 601.000 dan julmlah maksimumnya sebesar 781.000. sedangkan Perusahan Weha Transport Indonesia Tbk (WEHA) dan Perusahaan Mitra Internasional Resourch Tbk (MIRA) masing-masing memiliki jumlah perencaanaan pajak rata-rata sebesar 739,60000 dan 388,80000 dengan jumlah minimum 657.000 dan -1.342 .000 sedangkan jumlah maksimumnya sebesar 841.000 dan 1.297.000. maka dengan data tersebut di ketahui bahwa rata - rata perencanaaan 
Jurnal Akuntansi Manajerial ISSN (E): 2502-6704

Vol. 6, No. 1 Januari - Juni 2021: 1-19
Dipublikasikan oleh Fakultas Ekonomi dan Bisnis

Universitas 17Agustus 1945 Jakarta

http://journal.uta45jakarta.ac.id/index.php/JAM

pajak yang di lakukan ke-enam perusahaan tersebut memiliki jumlah rat-rata yang tidak berbeda jauh yang di hasilkan oleh analisis deskriptif.

Pada analisis deskriptif manajemen laba di ketahuai bahwa rata-rata tertinggi dilakukan oleh Perusahaan Blue Bird Tbk (BIRD) dengan jumlah rat-rata sebesar 93,00000 , lalu Perusahaan Mitra International Resourch Tbk (MIRA) memiliki rata-rata manajemen laba sebesar 42,00000 dengan nilai minimum sebesar -123,000 dan nilai maksimum sebesar 155,000. Perusahaaan Adi Sarana Armada Tbk (ASSA) memiliki rata-rata manajemen laba sebesar 31,60000 dengan nilai minimum sebesar $-41,000$ dan memiliki jumlah nilai maksimum sebesar 92,000. Perusahaan Expres Trasindo Utama Tbk (TAXI) memiliki jumlah rat-rata manajemen laba sebesar 29,80000 dengan nilai minimum sebesar $-3213,000$ dan nilai jumla maksimum manajemn labanya sebesar 2904,000. Perusahaan Eka Sari Lorena Transport Tbk (LRNA) memiliki jumlah rata-rata melakukan manajemen laba sebesar 13,60000 dengan jumlah minimumnya sebesar 628,000 dan jumlah manajemn laba maksimumnya sebesar 615,000. Lalu perusahaan yang paling rendah melakukan manajemen laba adalah Perusahaaan Weha Transport Indonesia Tbk (WEHA) perusahaan weha terdeteksi melakukan manajemen laba 10,20000 dengan jumlah minimum sebesar -60,000 dan jumlah maksimumnya sebesar 126,000.

Dengan analisis di atas kita dapat mengetahui bahwa perusahaan transportasi darat yang memiliki asset besar serta memiliki laba yang tinggi tidaklah jauh berbeda dengan perusahaan yang memiliki asset lebih kecil dalam perencanaan pajak dan manajemen laba, hal ini terjadi kemungkinan perusahaan ingin mencari aman dalam melakukan perencanaan pajak dan manajemen laba. Perusahaan yang mempunyai asset tinggi tentunya akan lebih di awasi oleh pemerintah dalam pelaporan laba serta dalam laporan perpajaknya denagn begitu tingkat perencanaan pajak dan manajemen laba antar perusahaan tidak begitu jauh berbeda.

Berdasarkan analisis deskriptif di atas menunjukan bahwa ke-enam perusaahaan memiliki rata-rata perencanaaan pajak dan manajemen laba yang tidak jauh berbeda sehingga penelitian ini bisa dilanjutkan ke uji berikutnya. 


\section{Uji Normalitas}

Secara umum ada dua metode untuk melakukan uji normalitas untuk one way anova dengan SPSS, yaitu dengan uji normalitas Kolmogorov smirnov dan uji Shapiro wilk. Adapun uji normalitas data Kolmogorov smirnov di pakai untuk data lebih dari 50 sample. Sementara uji Shapiro wilk dipakai untuk data penelitian kurang dari 50 sampel.

Table 4

\section{Uji Normaltas Data}

\begin{tabular}{|c|c|c|c|c|c|c|c|}
\hline \multicolumn{8}{|c|}{ Tests of Normality } \\
\hline & KODE & \multicolumn{3}{|c|}{ Kolmogorov-Smirnova } & \multicolumn{2}{|c|}{ Shapiro-Wilk } & \\
\hline & & Statistic & $\mathrm{df}$ & Sig. & Statistic & df & Sig. \\
\hline \multirow{6}{*}{$\begin{array}{l}\text { Manajemen } \\
\text { laba }\end{array}$} & BIRD & .276 & 5 & $.200 *$ & .912 & 5 & .481 \\
\hline & ASSA & .282 & 5 & $.200 *$ & .884 & 5 & .326 \\
\hline & LRNA & .178 & 5 & $.200^{*}$ & .986 & 5 & .964 \\
\hline & TAXI & .229 & 5 & $.200 *$ & .945 & 5 & .702 \\
\hline & MIRA & .276 & 5 & $.200^{*}$ & .917 & 5 & .510 \\
\hline & WEHA & .215 & 5 & $.200^{*}$ & .916 & 5 & .504 \\
\hline \multirow{6}{*}{$\begin{array}{l}\text { Perencanaan } \\
\text { Pajak }\end{array}$} & BIRD & .299 & 5 & .165 & .844 & 5 & .175 \\
\hline & ASSA & .235 & 5 & $.200^{*}$ & .852 & 5 & .203 \\
\hline & LRNA & .371 & 5 & .200 & .694 & 5 & .657 \\
\hline & TAXI & .262 & 5 & $.200 *$ & .931 & 5 & .604 \\
\hline & MIRA & .287 & 5 & $.200 *$ & .858 & 5 & .223 \\
\hline & WEHA & .149 & 5 & $.200 *$ & .983 & 5 & .950 \\
\hline
\end{tabular}

Sumber data: Data diolah dengan SPSS versi 25.0

Berdasarkan table di atas, diperoleh nilai Shapiro-wilk sig untuk data Perusahaan Blue Bird Tbk (BIRD ) pada variable manajemn laba dan perencanaan pajak mempunya nilai sig. masing-masing 0.481 dan 0.175 yaitu > 0.05. Perusahaan Adi Sarana Armada Tbk (ASSA) dilihat dari nilai Shapiro-wilk pada variable manajemn laba dan perencanaan pajak nya mempunyai nilai sig. masing-masing sebesar 0.326 dan 0.203 yaitu > 0.05. Perusahaaan Eka Sari Lorena Tbk (LRNA) mempunyai nilai sig. pada kolom Shapiro-wilk masing-masing variable nya sebesar 0.964 dan 0.657 yaitu > 0.05. Perusahaan Expres Trasindo Utama Tbk (TAXI) dilihat dari Shapiro-wilk pada masing-masing variable yaitu memiliki nilai sig. sebesar 0.702 dan 0.604 yai- 
tu > 0.05. Perusahaan Mitra International Resourch Tbk (MIRA) masing-masing variable pada Shapiro-wilk mempunyai nilai sig. sebesar 0.510 dan 0.223 yaitu $>0.05$. dan yang terakhir pada Perusahaan Weha Transport Indonesia Tbk (WEHA) masing-masing variable pada bagian Shapiro-wilk memiliki nilai sig. sebesar 0.504 dan 0.950 yaitu $>0.05$. berdasarkan dasar pengambilan keputusan dalam uji normalitas masing-masing perusahaan memiliki nilai sig > 0.05, dengan demikian dapat disimpulkan bahwa data ke-enam perusahaan transportasi darat (BIRD,ASSA,LRNA,TAXI,MIRA,dan WEHA) adalah berdistribusi normal. Karna syarat normalitas data telah terpenuhi maka penelitian ini bisa dilanjutkan tahap pengujian selanjutnya.

\section{Uji Homogenitas}

Tabel 5.

\section{Uji Homogenitas}

\begin{tabular}{|c|c|c|c|c|c|}
\hline \multicolumn{6}{|c|}{ Test of Homogeneity of Variances } \\
\hline & & $\begin{array}{c}\text { Levene Statis- } \\
\text { tic }\end{array}$ & df1 & $\mathrm{df} 2$ & Sig. \\
\hline \multirow{4}{*}{$\begin{array}{l}\text { Perencanaan } \\
\text { Pajak }\end{array}$} & Based on Mean & 9,587 & 5 & 24 & .320 \\
\hline & Based on Median & 2,615 & 5 & 24 & .281 \\
\hline & $\begin{array}{l}\text { Based on Median and } \\
\text { with adjusted df }\end{array}$ & 2,615 & 5 & 4,507 & .143 \\
\hline & $\begin{array}{l}\text { Based on trimmed } \\
\text { mean }\end{array}$ & 8,746 & 5 & 24 & .578 \\
\hline \multirow{4}{*}{$\begin{array}{l}\text { Manajemen } \\
\text { Laba }\end{array}$} & Based on Mean & 4,177 & 5 & 24 & .410 \\
\hline & Based on Median & 3,559 & 5 & 24 & .243 \\
\hline & $\begin{array}{l}\text { Based on Median and } \\
\text { with adjusted df }\end{array}$ & 3,559 & 5 & 5,191 & .091 \\
\hline & $\begin{array}{l}\text { Based on trimmed } \\
\text { mean }\end{array}$ & 3,995 & 5 & 24 & .390 \\
\hline
\end{tabular}

Sumber data: Data diolah dengan SPSS versi 25.0

Berdasarkan table di atas pada variable perencanaan pajak diketahui nilai signifikansinya (sig) based on mean sebesar $0.320>0.05$ dan berdasarkan output di atas pada variable manajemen laba diketahui nilai signifikansinya (sig) based on mean sebesar $0.410>0.05$, sehingga dapat disimpulkan bahwa varians dari perencanaan pajak dan manajemen laba adalah sama atau (Homogen). Data pada masing-masing perusahaan di ketahui bersifat homogen dan sesuai dengan kriteria pengujian. Dengan demikian, maka syarat homogenitas dari uji anova sudah terpenuhi. 
Jurnal Akuntansi Manajerial

ISSN (E): 2502-6704

Vol. 6, No. 1 Januari - Juni 2021: 1-19
Dipublikasikan oleh Fakultas Ekonomi dan Bisnis

Universitas 17Agustus 1945 Jakarta http://journal.uta45jakarta.ac.id/index.php/JAM

\section{Uji Anova}

Table 6.

Uji Anova

\begin{tabular}{|l|l|c|c|c|c|c|}
\hline \multicolumn{9}{|c|}{ ANOVA } \\
\hline \multicolumn{2}{|c|}{} & Sum of Squares & $\mathrm{df}$ & Mean Square & $\mathrm{F}$ & Sig. \\
\hline $\begin{array}{l}\text { Perencanaan } \\
\text { Pajak }\end{array}$ & $\begin{array}{l}\text { Between } \\
\text { Groups }\end{array}$ & 1096292,967 & 5 & 219258,593 & 1,033 & .421 \\
\cline { 2 - 8 } & Within Groups & 5095476,400 & 24 & 212311,517 & & \\
\cline { 2 - 8 } & Total & 6191769,367 & 29 & & & \\
\hline $\begin{array}{l}\text { Manajemen } \\
\text { Laba }\end{array}$ & $\begin{array}{l}\text { Between } \\
\text { Groups }\end{array}$ & 29572605,367 & 5 & 5914521,073 & 0,837 & .537 \\
\cline { 2 - 8 } & Within Groups & 169597166,000 & 24 & 7066548,583 & & \\
\cline { 2 - 8 } & Total & 199169771,367 & 29 & & & \\
\hline
\end{tabular}

Sumber data: Data diolah dengan SPSS versi 25.0

Berdasarkan tabel di atas diketahui pada kolom Sig. pada perencanaan pajak sebesar 0,421 $>$ 0,05 yang artinya hipotesis ditolak (Ha ditolak) dan menerima Ho yang artinya tidak terdapat perbedaan perencanaan pajak diantara keenam perusahaan tersebut. Sementara pada kolom sig. manajemen laba diperoleh sig. sebesar 0,537 > 0,05 yang artinya menerima Ho dan menolak Ha, yang artinya tidak terdapat perbedaan manajemen laba di antara keenam perusahaan tersebut. Hasil uji anova di atas diketahui bahwa penelitian ini sejalan dengan penelitian yang dilakukan oleh Husain et al., (2016) yang menunjukkan bahwa tidak terdapat perbedaan yang signifikan antara perusahaan industri manufaktur dan sektor keuangan yang melakukan IPO tahun 20122016. Sehingga dapat disimpulkan tidak ada perbedaan dalam praktek perencanaan pajak dan manajemen laba di sektor transportasi darat.

\section{KESIMPULAN DAN SARAN}

\section{Kesimpulan}

Berdasarkan pembahasan yang telah disampaikan, maka hasil dari uji perbandingan perencanaan pajak dan manejemen laba antar keenam perusahaan transportasi subsektor transportasi darat yang terdaftar di BEI periode 2015 - 2019 menggunakan uji komparatif (analisis of variance) Anova, yaitu tidak terdapat perbedaan perencanaan pajak dan manajemen laba perusahan transportasi subsektor transportasi darat yang terdaftar di BEI periode 2015- 2019. 
Jurnal Akuntansi Manajerial

ISSN (E): 2502-6704

Vol. 6, No. 1 Januari - Juni 2021: 1-19
Dipublikasikan oleh Fakultas Ekonomi dan Bisnis

Universitas 17Agustus 1945 Jakarta

http://journal.uta45jakarta.ac.id/index.php/JAM

\section{Batasan Penelitian}

1. Penelitian terbatas hanya pada perusahaan transportasi darat dan tidak membahas semua jenis perusahaan.

2. Penelitian ini terbatas pada periode 2015-2019 dan tidak meneliti data diluar periode tersebut.

3. Penelitian ini terbatas hanya kepada perusahaan transportasi darat yang terdaftar di bursa efek Indonesia

\section{Saran}

1. Penelitian selanjutnya diharapkan bisa meneliti lebih luas lagi dengan menggunakan populasi dan sampel yang berbeda, Hal ini ditujukan agar dapat memperluas hasil pengujian yang lebih akurat lagi.

2. Penelitian selanjutnya diharapkan bisa mengukur variabel perencanaan pajak dan manajemen laba dengan menggunakan metode pengukuran yang berbeda, hal ini ditujukan agar mendapatkan keakuratan hasil penelitian dan agar bisa di bandingkan hasilnya dengan penelitian-penelitian sebelumnya.

\section{DAFTAR PUSTAKA}

Accounting, I., Yulizar, A., Bandung, P. N., Apriliawati, Y., \& Bandung, P. N. (2020). Pengaruh Perubahan Tarif Terhadap Kepatuhan Wajib Pajak UMKM Sebelum Dan Sesudah PP No . 23 Tahun 2018 Di Kota Bandung ( Studi Kasus Wajib Pajak UMKM Pada KPP Pratama Bojonagara Dan KPP Pratama Cibeunying ) The Effect of Tariff Changes on SME Taxpayer Com. 1(1), 130-140.

Achyani, F., \& Lestari, S. (2019). PENGARUH PERENCANAAN PAJAK TERHADAP MANAJEMEN LABA (Studi Empiris Pada Perusahaan Manufaktur yang Terdaftar di Bursa Efek Indonesia Tahun 2015-2017). Riset Akuntansi Dan Keuangan Indonesia, 4(1), 77-88. https://doi.org/10.23917/reaksi.v4i1.8063

Ayu, B. D. P. (2019). Pengaruh Insentif Pajak Dan Insentif Non-Pajak Terhadap Manajemen Laba. Skripsi.

Dan, K., Syariah, B., \& Indonesia, D. I. (2018). Studi Komparatif Praktik Earnings Management Pada Bank. September. 
Jurnal Akuntansi Manajerial

ISSN (E): 2502-6704

Vol. 6, No. 1 Januari - Juni 2021: 1-19
Dipublikasikan oleh Fakultas Ekonomi dan Bisnis

Universitas 17Agustus 1945 Jakarta http://journal.uta45jakarta.ac.id/index.php/JAM

Hapsari, D. P., \& Manzillah, D. (2016). Pengaruh Perencanaan Pajak Terhadap Manajemen Laba Dengan Arus Kas Operasi Sebagai Variabel Kontrol (Studi Pada Perusahaan Manufaktur Sub Sektor Otomotif Dan Komponen Terdaftar Di Bursa Efek Indonesia (Bei) Periode 2011-2015). Jurnal Akuntansi, 3(2), 54-65.

Husain, T., Surachman, A. E., No, J. C., \& Barat, J. (2016). Praktik manajemen laba : studi komparasi pada perusahaan-perusahaan yang melakukan ipo tahun 2012- 2016. 21-30.

Maturidi. (2017). Analisi Komparatif Kinerja Keuangan Sebelum dan Sesudah Penerapan IFRS. Journal Ilmiah Rinjani, Vol. 5, No.

Nuariyanti, N. K. I., \& Erawati, N. M. A. (2014). Analisis Komparatif Kinerja Perusahaan Sebelum Dan Sesudah Konversi Ke Ifrs. E-Jurnal Akuntansi Universitas Udayana, 6(2), 274-286.

Puji Astutik, R. E. (2016). Pengaruh Perencanaan Pajak Dan Beban Pajak Tangguhan. Jurnal Ilmu \& Riset Akuntansi, 5(3).

Simanjuntak, W., \& Siahaan, S. (2016). Analisis Laporan Keuangan Untuk Menilai Kinerja Keuangan Perusahaan Studi Komparatif Pt Telkom Indonesia Dan Sk Telecom. Jurnal Ilmiah Methonomi, 2(2), 197038.

Sumomba, C., \& Hutomo, Y. (2012). Pengaruh Beban Pajak Tangguhan dan Perencanaan Pajak terhadap Manajemen Laba. Kinerja Journal of Business and Economics, 16(2), $103-115$.

Suputra, D. (2017). Pengaruh Mekanisme Corporate Governance dan Beban Pajak Tangguhan terhadap Manajemen Laba (Studi Empiris pada Perusahaan Manufaktur yang Terdaftar di Bursa Efek Indonesia Periode 2014-2016). E-Jurnal Akuntansi Universitas Udayana, 20(3), 2045-2072.

Yuniati, D. S. A. L., Kurnia, I., \& Yuniati. (2018). Pengaruh Perencanaan Pajak dan Ukuran Perusahaan Terhadap Manajemen Laba (Studi Empiris Pada Perusahaan Manufaktur Yang Terdaftar Di Bursa Efek Indonesia Periode 2015-2017). Jurnal Ilmiah MEA (Manajemen, Ekononi, \& Akuntansi), 2(3), 129-150. 